\title{
ISOLATION OF THE PIPERINE COMPOUND FROM BLACK PEPPER (Piper nigrum) IN THE PREPARATION OF STANDARD COMPOUNDS FOR PRACTICE AND RESEARCH ACTIVITIES
}

\author{
Lalu Sulman \\ Laboratory of Chemistry Education Department, FKIP University of Mataram, Mataram, Indonesia \\ Email: sulmanlaluunram@gmail.com
}

Accepted: October, 24 2021. Approved: November, 10 2021. Published: November, 302021

\begin{abstract}
Research conducted to meet the needs of standard compounds in practical and research activities. The use of standard compounds improves the quality of a study. Piperine is the main secondary metabolite compound of the alkaloid group contained in Black Pepper Piper nigrum L. The isolation method used is reflux and recrystallization methods. The reflux process in absorbing piperine compounds with diethyl ether solvent will help break down the cell walls to absorb the compounds optimally. Recrystallization was repeated 7-8 times until the crystals were pale yellow. The purity test used the TLC test with a solvent ratio of $n$-hexane and chloroform 6:4 with an Rf value of $0.04 \mathrm{~cm}$. GCMS confirmation of $85 \%$ purity, UV-Visible spectroscopic test maximum wavelength 343 with absorbance 0.865 and FTIR test confirmed wave number $928 \mathrm{~cm}-1$ (CO), 996 cm-1 ((CH bending of trans $-\mathrm{CH}=\mathrm{CH}-), 1028 \mathrm{~cm}-1$ (=COC sym. st.), $1250 \mathrm{~cm}-1$ (=COC asym. st.), $1440 \mathrm{~cm}-1$ (methylenedioxy CH2bending), $1581 \mathrm{~cm}-1$ (arom. C=C st.), $1631 \mathrm{~cm}-1$ (-CO-N-). Based on the confirmed test results, the isolated compound is piperine from the alkaloid group. Piperine compounds can be used as standard compound preparations for testing the purity of compounds in research and chemistry lab work on natural ingredients.
\end{abstract}

Keywords: Isolation, Black pepper, reflux, recrystallization, piperin, standard compound

\section{INTRODUCTION}

Black pepper (Piper nigrum L) is an ingredient commonly used as a food seasoning. Black pepper is widely sold in the market at a low price. Black pepper contains piperine which is a class of alkaloid compounds [1]. Alkaloids are widely used as antioxidants, antibacterial, digestive problems, arthritis, and anti-cancer [2-3]. Piper nigrum, a plant from the Piperaceae, is remarkable for the presence of piperine alkaloids. Piperine has an important role in increasing the bioavailability of many drugs [4].

Laboratory research on black pepper extract requires standard compounds as the basis for determining which piperine compounds have activity against test bacteria. Standard compounds take a long time and a high price to obtain. The current popular standard compound preparation is Sigma Aldrich. Researchers were hampered by the implementation time to carry out the laboratory test process due to the unavailability of standard compounds. The standard compound determines the quality of the tests carried out in the practice and research activities in the laboratory.

Many researchers have carried out the isolation of piperine compounds from black pepper. Piperine was isolated using the gravity column chromatography method yielding $800 \mathrm{mg}$ [5]. Piperin isolation using the modification of extraction method of Double Bypasses Sidearm Soxhlet Apparatus (DBSA) yielded $0.8 \mathrm{~g}$ of crude piperine [6]. The very small piperine compound does not meet the number of needs if it is used as a test standard compound in phytochemicals, antioxidant, antifungal, and antibacterial tests in practical activities and chemical research on natural materials and microbiology.

Modification of isolation procedures is needed to meet the needs of standard compounds with simple tools and technical materials that are easily available at low prices. Diethyl ether is a material that has a pungent odor and evaporates at room temperature. A Diethylether solvent was used to look for semi polar which is expected as potential antioxidants [7]. The reflux process used was the maceration process at hot temperatures with a low boiling point solvent. The reflux process in absorbing the target compound using a fume hood to avoid inhalation of diethyl ether vapor by researchers as a result of the inability of the coolant to retain solvent vapor will support to break down cell walls so that the compound can be absorbed optimally [8-10]. Heating causes swelling and tremendous coalescence of the oil cells and other constituents. The breakdown of the cell wall provides easy access for solvent penetration. The cell wall is mainly composed of cellulose which is slightly ionic; there is a noticeable increase in the heating rate. There is a rapid degradation of the cellulose cell wall, thereby increasing the permeability of the wall to solvent penetration.

The process of purity was carried out using recrystallization. The Re-crystallization method was a compound purity process that is carried out by redissolving the crystal in the less favored solvent [11]. Piperine is a polar compound that is dissolved by heating with diethyl ether solvent. In cold conditions, piperine will recrystallize. The process is carried out until the pure piperine crystal is obtained. The recrystallization 
method was used to obtain a greater amount of pure compound so that it can be used as the standard compound.

The use of simple tools and technical solvent material will reduce the budget of the isolation process in obtaining pure piperine in a greater amount. The study is expected to provide the standard compound for the research of piperine isolation, phytochemical, antioxidant, antifungal, and antibacterial tests of black pepper extract in practical and research activities.

\section{RESEARCH METHOD \\ Type of Research}

The study is an experimental laboratory study. There are two variables in the study which consist of independent and dependent variables. The independent variable is a variable that influences or causes the dependent variable to arise, while the dependent variable is a variable that is influenced or is the result of an independent variable [12]. The independent variable in this study was the simplification of the pure compound isolation procedure using hot solvent and recrystallization. The dependent variable in this study was the pure compound piperine.

The research design consists of the preparation, compound isolation, and compound purity test stages. The preparation stage consists of the process of preparing Simplicia from dry black pepper and preparing a reflux device. The isolation stage carried out was the recrystallization process of reflux results. The crystal compounds obtained were tested for purity by TLC test, GCMS test, UV-Vis spectrophotometry test, and FTIR test.

\section{Preparation Stage}

\section{Simplicia}

$1 \mathrm{~kg}$ of dried black pepper was mashed using a blender into a smaller but not smooth shape. Simplicia was separated as much as 100 grams as an ingredient in the isolation process.

\section{Reflux Tool Settings}

This research used a hot solvent method with reflux. The reflux was prepared in advance to facilitate the isolation process. The solvent used in the reflux method was a liter of diethyl ether. The condenser water circulation in this process was controlled using an aerator with the support of ice cubes. The result of the recrystallization process is purity using a TLC plate.

\section{Compound Isolation Stage}

The reflux process is a method of maceration with the support of heating in which the solvent is maintained in the system by reverse cooling. Reflux is used for maximum absorption of the target compound in Black Pepper. Diethyl ether solvent is a low boiling point solvent. Reverse cooling plays an important role in this process to maintain the presence of solvent in the system. The reflux process was carried out for 2 hours. The obtained macerate was evaporated using an evaporator for 30 minutes until a thick extract was obtained. The extract was stored in the refrigerator for 1 week until crystals formed.

The dirty crystal, which was the target compound, was separated from the solvent. The crystals were dissolved again using diethyl ether and fired until all the crystals were dissolved. The macerate was evaporated to half of its initial volume and cooled again in the refrigerator. The crystals formed were undergoing the recrystallization process of 7 times until white crystals were obtained.

\section{Compound Purity Test Stage}

Obtained piperine compound was tested using KLT to determine the one spot as the result, gas chromatography-mass spectrometry (GCMS) test, UV absorption test, and FTIR test to confirm the compound of the obtained crystal.

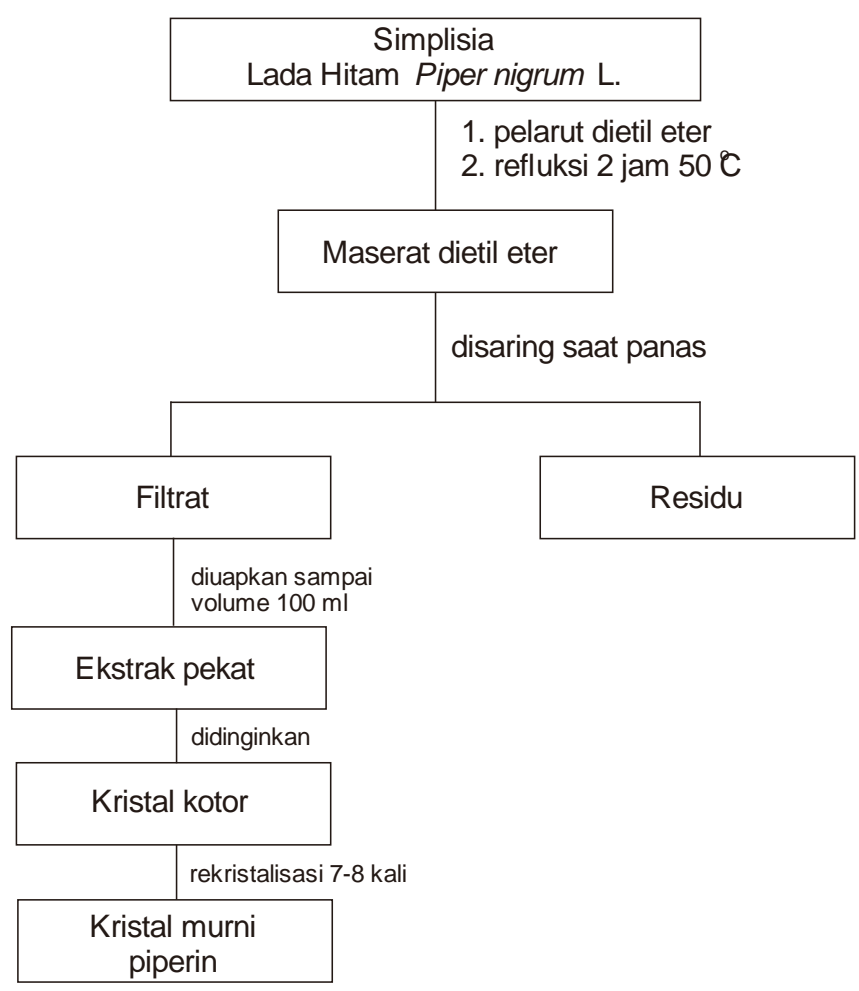

Figure 1. Scheme procedure of piperine isolation 


\section{RESULTS AND DISCUSSION}

Black pepper is a spice that is often found in everyday life. This spice is widely used as a food seasoning. Black pepper has a small black round shape and has a spicy taste. Black pepper is easily available in the market at a relatively low price. All circles of society can get black pepper in fulfilling their needs. However, black pepper contains active compounds that can be used as antiviral, antibacterial, anti-inflammatory, analgesic and antipyretic, and anti-cancer [13]. This active compound is a secondary metabolite compound from the alkaloid group, namely piperine compounds [14].

Piperine has high appeal due to its medicinal properties and as a bioavailability enhancer in the formulation of several drugs [15]. Piperine compounds are soluble in nonpolar solvents but insoluble in polar solvents such as water. Piperine has a melting point of $129-130^{\circ} \mathrm{C}$ [16].

\section{Reflux Process}

Reflux is an extraction method using heat. The process of absorption of active compounds was carried out by damaging plant cell membranes to enable optimal absorption. The use of reflux in the isolation process was due to the use of diethyl ether solvent which is toxic and very pungent. Reflux is carried out in a fume hood. The hot steam which didn't condense back was immediately wasted into the ambient air so that the researcher would not absorb it. The back cooler and fume hood protect students during the implementation of the process in the learning activity. The use of the method was by the conditions of the solvent used.

Reflux produced extract after evaporation process. The extract was stored in a refrigerator for the purpose of crystallizing the active compound in a saturated state. The dominant compound will crystallize or precipitate under low temperature conditions.

\section{Purification Process}

Purification is the process of purification of secondary metabolites to become dominant compounds in plant extracts. The saturated extract undergoes a crystallization process. Crystals are dirty crystals with a lot of impurity compounds. Impurities are minimized and removed by the recrystallization process. Recrystallization is one of the purification processes in the isolation of pure natural compounds. The dirty crystals were redissolved with diethyl ether and re-saturated. The saturated black pepper sample was cooled again in the refrigerator to form cleaner crystals. Some of the impurities are in the discarded filtrate. This process was repeated seven times until pure crystals were formed.

\section{Compound Purity Test}

Thin Layer Chromatography (TLC)

The clean crystals obtained in the purification process were carried out with a qualitative spot test using the TLC method. The TLC test results showed that the isolated compound was a pure compound which was characterized by the appearance of a single spot on the TLC plate (figure 1). The TLC plate is made of nonpolar silica. The Rf value in the TLC test depends on the type of solvent used. The spot test for piperine used a solvent ratio of n-hexane and chloroform with a ratio of 9:1 (b), 8:2 (c), and 6:4 (d). The Rf values of piperine were $0.00 \mathrm{~cm}, 0.05 \mathrm{~cm}$, and $0.40 \mathrm{~cm}$, respectively, which indicated that the compound was polar. However, the TLC method is not sufficient to determine the purity of a compound.

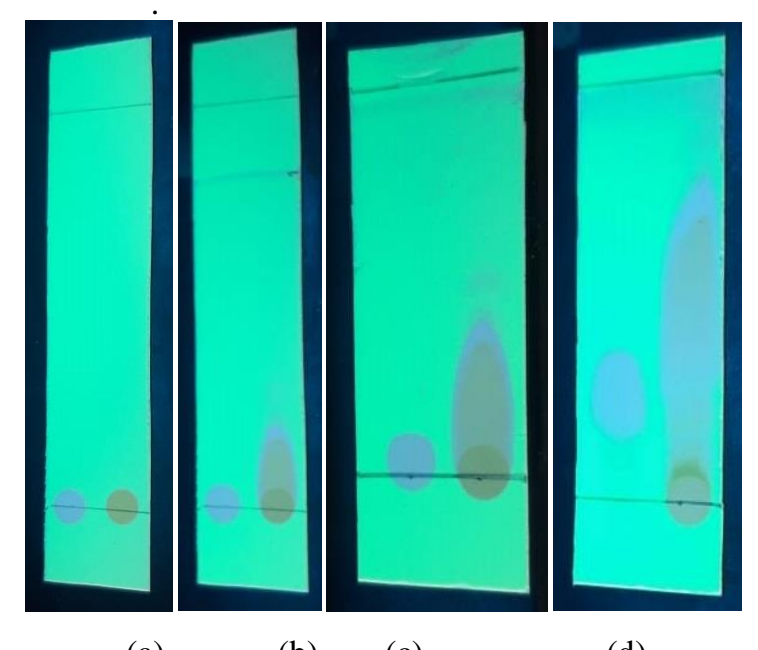
(a)
(b)
(c)
(d)

Figure 2. Qualitative Test Result of TLC

\section{Confirmation of GCMS}

GCMS is a method of separating organic compounds, including gas chromatography (GC) to analyze the number of compounds quantitatively and mass spectrometry (MS) to analyze the molecular structure of analyte compounds [17]. Quantitative and qualitative methods used to determine the purity of compounds were confirmed by the GCMS method. The results of the GCMS test indicated the percentage of the compound presence in the test sample. The compound suspected to have been isolated from piperine showed a purity of up to $85 \%, 15 \%$ of which was an impurity compound (figure 2). The compound with a purity of above $80 \%$ can be used as a test to the next stage, namely UV-Vis and FTIR tests. GCMS test was a determinant for the next test stage. If the purity of the compound is below $80 \%$, it will not proceed to the UV-Vis and FTIR tests. The compound sample must be re-crystallized to purity above $80 \%$. 
Table 1. The Results of GCMS

$\begin{array}{rrrr}\text { Peak\# } & \text { R.Time } & \text { I.Time } & \text { F.Time } \\ 1 & 3.067 & 3.015 & 3.115 \\ 2 & 4.031 & 3.985 & 4.050 \\ 3 & 4.596 & 4.585 & 4.680 \\ 4 & 5.095 & 5.075 & 5.185 \\ 5 & 5.235 & 5.185 & 5.255 \\ 6 & 5.265 & 5.255 & 5.280 \\ 7 & 5.300 & 5.280 & 5.330 \\ 8 & 5.953 & 5.330 & 5.975 \\ 9 & 6.150 & 6.120 & 6.165 \\ 10 & 6.340 & 6.295 & 6.355\end{array}$

\begin{tabular}{|c|c|c|c|c|c|c|}
\hline \multicolumn{7}{|c|}{ Peak Report TIC } \\
\hline Area & Area $\%$ & Height & Height $\%$ & $\mathrm{~A} / \mathrm{H}$ & Mark & Name \\
\hline 56031084 & 2.73 & 13563475 & 3.80 & 4.13 & & ETHYL ISO-ALLOCHOLATE \\
\hline 2535671 & 0.12 & 929144 & 0.26 & 2.73 & & \\
\hline 2780477 & 0.14 & 904500 & 0.25 & 3.07 & & \\
\hline 25312040 & 1.23 & 2616899 & 0.73 & 9.67 & V & RT:5.095 \\
\hline 34418441 & 1.67 & 9351727 & 2.62 & 3.68 & V & \\
\hline 15573503 & 0.76 & 10456065 & 2.93 & 1.49 & $\mathrm{~V}$ & \\
\hline 35820674 & 1.74 & 12007553 & 3.36 & 2.98 & $\mathrm{~V}$ & \\
\hline 1754741860 & 85.36 & 111957652 & 31.35 & 15.67 & V & 1-Nonadecene (CAS) \\
\hline 59990978 & 2.92 & 90602620 & 25.37 & 0.66 & & 1-Tridecene (CAS) n-Tridec-1-ene \\
\hline 68371007 & 3.33 & 104750011 & 29.33 & 0.65 & & 1-Tridecene (CAS) n-Tridec-1-ene \\
\hline 2055575735 & 100.00 & 357139646 & 100.00 & & & \\
\hline
\end{tabular}

\section{UV-Vis Spectrophotometer}

The peak of the UV spectrophotometer test results showed the highest peak at a wavelength of $343 \mathrm{~nm}$ using chloroform solvent with an absorbance of 0.865 . The determination of piperine from black pepper using the UV-Vis

spectrophotometer method showed a maximum peak at a wavelength of $343 \mathrm{~nm}$ [18]. The absorbance measurement at a wavelength of 345 $\mathrm{nm}$ showed that it was compatible with the isolation of black pepper conducted by Fagen in 1955, namely piperine.

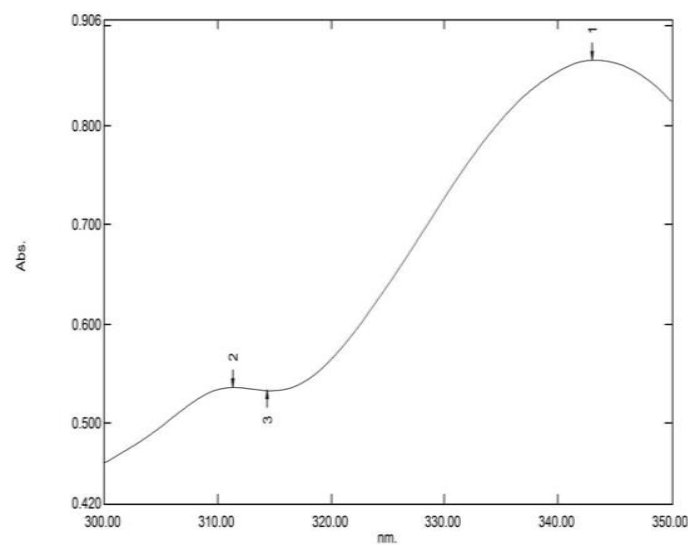

(a)

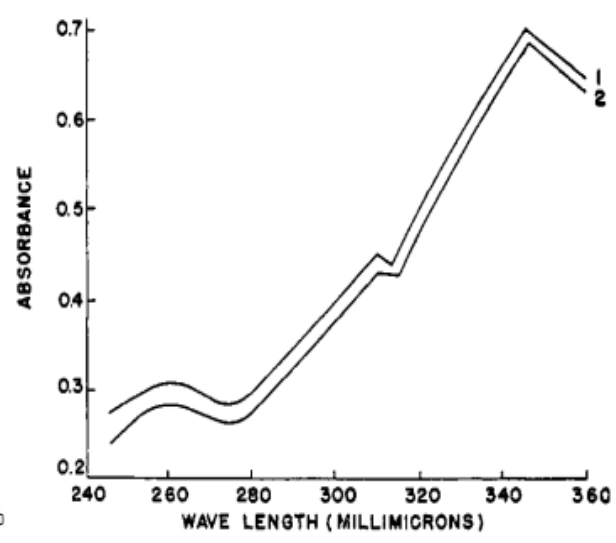

(b)

Figure 3. (a) Spectrum of UV-Vis Spectrophotometer of piperin, (b) Spectrum of UV-Vis Spectrophotometer of piperin

\section{Fourier Transform Infra-Red (FTIR) Spectrophotometer \\ The piperine structure was confirmed by} FTIR spectroscopy, as to how we're done in UVVis and IR spectroscopy, piperine compounds were isolated with few impurities. The wavenumber (figure 4) corresponds to the wavenumber of 928 cm-1 (CO), $996 \mathrm{~cm}-1$ ((CH bending of trans -
$\mathrm{CH}=\mathrm{CH}-), 1028 \mathrm{~cm}-1$ (=COC sym. st.), $1250 \mathrm{~cm}-1$ (=COC asym. st.), $1440 \mathrm{~cm}-1$ (methylenedioxy CH2bending), $1581 \mathrm{~cm}-1$ (arom. $\mathrm{C}=\mathrm{C}$ st.), 1631 cm-1 (-CO-N-) [19]. The impurity compounds were detected at a wavenumber of $3500 \mathrm{~cm}-1$. The type and weight of the impurity compounds can be seen in the results of the GCMS test (table 1).

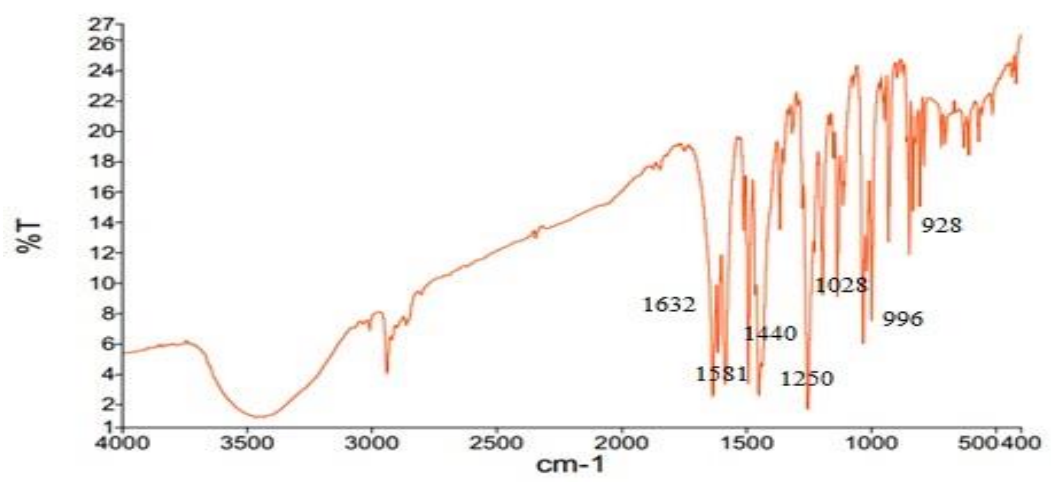

Figure 4. The Results of FTIR in Piperine 


\section{REFERENCES}

[1] Putri, I. Z., \& Sumarno, S. (2017). Perbedaan Efek Antibakteri Ekstrak Etanol Lada Hitam (Piper Nigrum L.) dengan Ekstrak Etanol Lada Puth (Piper Nigrum L.) terhadap Streptococcus Mutans secara In Vitro. EProdenta Journal of Dentistry, 1(1), 1-7.

[2] Vasavirama, K.and Upender, M., 2014, Piperine: A Valuable Alkaloid from Piper Species, International Journal of Pharmacy and Pharmaceutical Sciences, 6 (4): 34-38.

[3] Hakim, A., Loka, I. N., Hajar, S., \& Junaidi, E. (2020). Isolation and Confirmation of Quercetin-3-O-Glycosides from Rubber Cassava Leaves. Natural Resources, 11(9), 420-425.

[4] Chithra, S., Jasim, B., Sachidanandan, P., Jyothis, M., \& Radhakrishnan, E. K. (2014). Piperine production by endophytic fungus Colletotrichum gloeosporioides isolated from Piper nigrum. Phytomedicine, 21(4), 534-540.

[5] Hakim, A., \& Jufri, A. W. (2018). Natural products laboratory project: Isolation and structure elucidation of piperin from piper nigrum and andrographolide from Andrographis paniculata. Journal of Turkish Science Education, 15(4), 15-28.

[6] Subramanian, R., Subbramaniyan, P., Ameen, J. N., \& Raj, V. (2016). Double bypasses soxhlet apparatus for extraction of piperine from Piper nigrum. Arabian journal of chemistry, 9, S537-S540.

[7] Mulangsri, D. A. K., Budiarti, A., \& Saputri, E. N. (2017). Aktivitas antioksidan fraksi dietileter buah mangga arumanis (Mangifera indica L.) dengan metode DPPH. Jurnal Pharmascience, 4(1).

[8] Kusnadi, K., \& Devi, E. T. (2017). Isolasi dan Identifikasi Senyawa Flavanoid pada Ekstrak Daun Seledri (Apium graveolens L.) dengan Metode Refluks. PSEJ (Pancasakti Science Education Journal), 2(1).

[9] Zhang, Q. W., Lin, L. G., \& Ye, W. C. (2018). Techniques for extraction and isolation of natural products: a comprehensive review. Chinese medicine, 13(1), 20.

[10] Pramono, A., Fauzantoro, A., Hidayati, I. R., Hygea, A., Puspita, O. S., Muktamiroh, H., ... \& Gozan, M. (2018, March). In vitro assay of ethanolic heat reflux extract of Nicotiana tabacum L. var Virginia against nosocomial bacteria pathogen. In Journal of Physics: Conference Series (Vol. 970, No. 1, p. 012021). IOP Publishing.
[11]Purwanto, B. T. (2018). Sintesis Senyawa N(2-klorobenzoil)-N'fenilurea dan uji aktivitasnya antikanker terhadap sel HeLa. Jurnal Ilmu Kefarmasian Indonesia, 16(2), 159-165.

[12] Sugiyono. 2017. Statistika Untuk Penelitian. Bandung: Alfabeta.

[13] Hikmawanti, N. P. E., Hariyanti, C. A., \& Viransa, V. P. (2016). Kandungan piperin dalam ekstrak buah lada hitam dan buah lada putih (Piper nigrum L.) yang diekstraksi dengan variasi konsentrasi etanol menggunakan metode KLT-densitometri. Media Farmasi, 13(2), 173-185.

[14] Hasriyani, H., Zulfa, A., Anggun, L., \& Murhayati, R. (2021). Uji Aktivitas Antibakteri Ekstrak Etanol 70\% Biji Lada Hitam (Piper nigrum L) Terhadap Bakteri Escherichia coli. Indonesia Jurnal Farmasi, 5(2), 14-18.

[15] Subramanian, R., Subbramaniyan, P., Ameen, J. N., \& Raj, V. (2016). Double bypasses soxhlet apparatus for extraction of piperine from Piper nigrum. Arabian journal of chemistry, 9, S537-S540.

[16] Kolhe, S.R., Borole, P., and Patel, U., 2011, Extraction and Evaluation of Piperine from Piper nigrum, Internasional Journal of Applied Biology and Pharmaceutical Technology, 144149.

[17]Pratama, D. G. A. Y., Bawa, I. G. A. G., \& Gunawan, I. W. G. (2016). Isolasi dan identifikasi senyawa minyak atsiri dari tumbuhan sembukan (Paederia foetida L.) dengan metode kromatografi gas-spektroskopi massa (GC-MS). Jurnal Kimia, 10(1), 149-154.

[18]Fagen, H. J., Kolen, E. P., \& Hussong, R. V. (1955). Spice analysis, spectrophotometric method for determining piperine in oleoresins of black pepper. Journal of Agricultural and Food Chemistry, 3(10), 860-862.

[19] Moraru, A. C., ROŞCA, I., CRĂCIUN, B., Nicolescu, A., Chiriac, A. E., \& Voicu, V. (2019). Insights of The Antimicrobial Activity Of Piperine Extracted From Piper Nigrum L. Farmacia, 67(6), 1099-1105. 